\title{
ПІДПРИєМницТВо
}

\section{STRATEGY FOR ENSURING ECONOMIC SECURITY OF MICRO- AND SMALL-SIZED ENTERPRISES}

\author{
Kateryna Astafieva \\ PhD (Economics), Associate Professor \\ e-mail: astafevakatia2017@gmail.com \\ ORCID ID: 0000-0002-3418-7622 \\ Hanna Temchenko \\ PhD (Economics), Associate Professor \\ e-mail: tomskogo3_2@ukr.net \\ ORCID ID: 0000-0002-0703-5041 \\ Olga Bondarchuk \\ PhD (Technical Science), Associate Professor \\ e-mail: om_bond@ukr.net \\ ORCID ID: 0000-0001-9366-2019 \\ Kryvyi Rih National University \\ 11, Vitaly Matusevich str, Kryvyi Rih, 50027, Ukraine
}

Current global trends encourage the consideration of measures to develop small and micro businesses. The aim of the article is to develop a strategy for economic security of small and microenterprises, which will ensure the development of enterprises in the future. When conducting a study of the state of development of the small and microenterprise system in Ukraine, the method of statistical grouping, based on typological features and analytics, was used. To characterize economic security and highlight threats to development, the method of generalization and comparison was used. The paper studies the dynamics of the development of a small and microenterprise system of Ukraine. It was determined that during the period 20112018 there was a decrease in the number of small and microenterprises by $17.5 \%$. The abovementioned regulates the feasibility of developing a system of ensuring economic security, which will prevent a decrease in the number of enterprises of a small and micro business in the future. Business development experience shows that a proposed system must take into account the specifics of small and microenterprises. The study showed that the state of economic security is due to protection from a number of economic threats. In the conditions of a small and microenterprise, economic threats should be grouped according to the direction of their implementation. The article singles out the following threats: of innovation, competition, enterprise, finance and jurisprudence. In this regard, the economic security structure should provide for the neutralization of the negative consequences of the threats of the components: innovative security, competitive security, business security and financial and legal security. In order to neutralize the negative consequences of the implementation of threats to economic security, it is advisable to propose a partnership agreement strategy. The latter includes the development of partnership agreements in the areas of marketing, logistics, integration, legal and financial cooperation.

Keywords: Strategy, Economic Security, Threats, Microenterprises, Business, Partnership.

JEL Classification: D10; D21; L19. 


\title{
СТРАТЕГІЯ ЗАБЕЗПЕЧЕННЯ ЕКОНОМІЧНОЇ БЕЗПЕКИ МААИХ ТА МІКРОПІДПРИЕМСТВ
}

\author{
Астаф'єва Катерина Омександрівна \\ кандидат економічних наук, доцент \\ e-mail: astafevakatia2017@gmail.com; ORCID ID: 0000-0002-3418-7622 \\ Темченко Ганна Володимирівна \\ кандидат економічних наук, доцент \\ e-mail: tomskogo3_2@ukr.net; ORCID ID:0000-0002-0703-5041 \\ Бондарчук Омьга Михаймівна \\ кандидат технічних наук, доцент \\ e-mail: om_bond@ukr.net; ORCID ID: 0000-0001-9366-2019 \\ Криворізъкий наиіональний університет \\ вул. Віталія Матусевича, 11, Кривий Ріг, 50027, Украӥна
}

\begin{abstract}
Сучасні світові тенденції спонукають до розгляду заходів щодо розвитку малого та мікро бізнесу. Метою статті є розробка стратегії економічної безпеки малих та мікропідприємств, що дозволить забезпечити розвиток вказаних підприємств у майбутньому. При виконанні дослідження стану розвитку системи малого та мікропідприємництва в Україні було використано метод статистичного групування на основі типологічних ознак та аналітики. Задмя характеристики економічної безпеки та виокремлення загроз розвитку використано метод узагальнення і порівняння. У роботі виконано дослідження динаміки розвитку системи малого та мікропідприємства в Україні. Виявцено, що протягом 2011-2018 рр. має місце зменшення кількості підприємств малого та мікро бізнесу на 17,5 \%. Наведене регламентує доцільність розробки системи забезпечення економічної безпеки, яка дозволить упередити зниження кількості підприємств малого та мікро бізнесу у майбутньому. Досвід розвитку бізнесу показує, що запропонована система має враховувати особливості діяльності малих та мікропідприємств. Дослідження показало, що стан економічної безпеки обумовлений захищеністю від низки економічних загроз. В умовах малого та мікропідприємства економічні загрози доцільно згрупувати в залежності від напряму їх реалізації. У статті запропоновано розглядати загрози наступного характеру: інновацій, конкуренції, підприємства, фінансів та юриспруденції. У зв'язку із цим структура економічної безпеки повинна передбачати нейтралізацію негативних наслідків загроз складових: інноваційної безпеки, безпеки конкурентоспроможності, безпеки підприємництва та фінансово-юридичної безпеки. 3 метою нейтралізації негативних наслідків реалізації загроз економічної безпеки доцільно запропонувати стратегію партнерських угод. Остання включає в себе розробку партнерських угод у напрямках: маркетингового, могістичного, інтеграційного, юридичного та фінансового співробітництва.
\end{abstract}

Ключові слова: стратегія, економічна безпека, загрози, мікропідприємства, бізнес, партнерство.

JEL Classification: D10; D21; L19.

\section{СТРАТЕГИЯ ОБЕСПЕЧЕНИЯ ЭКОНОМИЧЕСКОЙ БЕЗОПАСНОСТИ МААЫХ И МИКРОПРЕДПРИЯТИЙ}

\author{
Астафьева Катерина Амександровна \\ кандидат экономических наук, доцент \\ e-mail: astafevakatia2017@gmail.com \\ ORCID ID: 0000-0002-3418-7622 \\ темченко Анна Виадимировна \\ кандидат экономических наук, доцент \\ e-mail: tomskogo3_2@ukr.net \\ ORCID ID: 0000-0002-0703-5041 \\ Бондарчук Оцьга Михайцовна \\ кандидат технических наук, доцент \\ e-mail: om_bond@ukr.net \\ ORCID ID: 0000-0001-9366-2019
}

Криворожский национальный университет

ул. Виталия Матусевича, 11, Кривой Рог, 50027, Украина

Современные мировые тенденции побуждают к рассмотрению мер по развитию малого и микро бизнеса. Целью статьи является разработка стратегии экономической безопасности малых и микропредприятий, что позволит обеспечить развитие предпринимательства в будущем. При выполнении исследования состояния развития системы малого и микропред- 
принимательства в Украине был использован метод статистического группирования на основе типологических признаков и аналитика. Для характеристики экономической безопасности и выделения угроз развитию использованы методы обобщения и сравнения. В работе выполнено исследование динамики развития системы малого и микропредпринимательства в Украине. Определено, что в течение 2011-2018 гг. имеет место уменьшение количества предприятий малого и микробизнеса на 17,5 \%. Приведенные данные регламентирует целесообразность разработки системы обеспечения экономической безопасности, которая позволит предотвратить уменьшение количества предприятий малого и микро бизнеса в будущем. Опыт развития бизнеса показывает, что предложенная система должна учитывать особенности деятельности малых и микропредприятий. Исследование показало, что состояние экономической безопасности обусловлено защищенностью от ряда экономических угроз. В условиях малого и микропредприятия экономические угрозы целесообразно сгруппировать в зависимости от направления их реализации. В статье предложено рассматривать угрозы следующего характера: инноваций, угрозы конкуренции и предпринимательства, а также финансов и юриспруденции. В связи с этим, структура экономической безопасности должна предусматривать нейтрализацию негативных последствий реализации угроз: инновационной безопасности, безопасности конкурентоспособности, безопасности предпринимательства и фринансово-юридической безопасности. С целью нейтрализации негативных последствий реализации угроз экономической безопасности цемесообразно предможить стратегию партнерских соглашений. Последняя вкцючает в себя разработку партнерских связей по направлениям: маркетингового, могистического, интеграционного, юридического и финансового сотрудничества.

Кмючевые смова: стратегия, экономическая безопасность, угрозы, микропредприятия, бизнес, партнерство.

JEL Classification: D10; D21; L19.

Problem statement. International experience indicates that most of the welfare of the state is contained in a developed system of small and microenterprises. In world practice, much attention is paid to the economic support of a small enterprise in terms of risk insurance and the development of a selffinancing system. For Ukrainian realities, it is important to provide both support and development of a small and micro-enterprise system. The state is trying to carry out its functions effectively, but a lot of responsibility is put on the entrepreneur - an individual.

It is important to develop modern scientific works in the context of determining the essence of economic security in order to identify the features of ensuring the latter in small and microenterprises.

Developing a small and micro business is always difficult, as there are a lot of threats on the way to success. Therefore, ensuring economic security is important, it will take into account the characteristic threats of small and microenterprises. In turn, to prevent the negative consequences of the implementation of threats, it is necessary to consider strategies for ensuring economic security.

Literature review. Considering the national and foreign methods of ensuring the economic security of enterprises, we can say that there are quite diverse approaches that use different sizes, indicators and categories. At the same time, some issues of assessment of economic security of enterprises have not been solved in the current conditions of economic activity. So, the issues of economic security threats assessment for small and microenterprises will not be sufficiently solved.

Analysis of literary sources was performed for the period 2009-2019. Let's start by considering the concept of 'economic security'. Researcher J. O. Zajac notes that the concept of 'economic security' is appropriate to understand the state of protection of business processes from external and internal threats (Zajac, 2016). An interesting approach to determining the essence and interpretation of economic security was proposed by a team of researchers N.K. Nazarov and I. A. Barannik (Nazarov \& Barannik, 2019). Researchers suggest that economic security should be understood as the symbiosis of all potential enterprise opportunities in the direction of using the resources of the latter. The above approach allows us to effectively perform all the functions of the enterprise from the point of view of its potential and neutralize the negative impact of economic threats both in external and internal environment.

Researchers A. V. Arefieva and T. B. Kuzenko (Arefieva \& Kuzenko, 2009), A. A. Kirichenko (Kirichenko and others, 2010) determine the economic security of an enterprise as the state of protection of the enterprise business processes from environmental threats. The economic meaning of this definition is defined through ensuring the competitiveness and financial stability of the enterprise.

Thoughts on the need to ensure economic security at the small and microenterprise level are reflected in Ion-France and Diamescu 
(2012). Researchers note that comprehensive measures to ensure the economic security of a country affect the level of financial and economic security of a person who is engaged in business (Ion-France \& Diamescu, 2012).

The Polish economist S. Efimovich Melev (Efimovich Melev, 2014) suggests that economic security means the totality of the state potential abilities to ensure the stable development of society and entrepreneurship with the prejudice of the emergence of external and internal threats.

In terms of ensuring economic security, it is important to distinguish the essence of the concepts of risk and threat. The work of researchers I. P. Mignus and S. M. Laptev (Mignus \& Laptev, 2011) indicated that the concept of "risk" and "threat" cannot be equated. This is due to the fact that "risk" implies a negative impact on the efficiency of the enterprise. And, in turn, the "threat" provides for a separate event that has an impact on the enterprise. Both of these categories can have negative consequences both in the short and long term.

O. V. Nusinova (2011) proposes to distribute threats to economic security to enterprise threats and economic threats to enterprise stakeholders. In turn, stakeholders are understood as shareholders, debtors, investors, creditors and others. When considering a number of relevant threats, it is necessary to focus on negative events that can occur under the influence of these factors. However, the above approach does not take into account market threats and the technical and economic component of the enterprise.

Consideration of the issue of identifying threats to economic security for small businesses is given in the work of the economists S. O. Tulchinskaya, T. P. Tkachenko and M. V. Grashchenko (Tulchinska, Tkachenko, \& Grashchenko, 2017). Economists note that the main threats to the development of small enterprises should include threats of imperfect legislation, administrative barriers, underdeveloped financial support system, lack of information support for enterprises and selffinancing tools.

Research methodology. The aim of the paper is to determine the current state of development of small and microenterprises in Ukraine and to develop a system for ensuring their economic security. The latter includes the main components that take into account the potential threats of small and micro businesses. To prevent the negative consequences of threats, it is advisable to propose a strategy for ensuring economic security.

Achieving the goal involves the following tasks: analysis of statistical information on the change in the number of small and microen- terprises in Ukraine; the study of the essence of economic security with the identification of threats to the activities of small and microenterprises; development of an economic security structure that takes into account threats from small and microenterprises; development of proposals for a partnership agreement strategy to ensure economic security.

In the course of the study, to identify the essence of economic security and develop its structure, the methodology of the system analysis was used. The study of replacing the number of small and microenterprises was carried out using the methods of statistical grouping based on typological features, as well as methods of generalization, comparison and analytics. Information on the number of small and microenterprises in Ukraine was obtained from the official website of state statistics (Derzhkomstat, 2020).

Main results. In order to identify the current state of development of small and microentrepreneurship in Ukraine, a study was conducted on the dynamics of the number of a given group of business entities. The analysis was carried out over the past eight years, and the results of calculations, for clarity of presentation of the material, are depicted in the histogram below.

According to Fig. 1, in recent years, there has been a decrease in the number of small and microenterprise entities in Ukraine.

So, in 2011 there was a decrease in the number of small enterprises by $22.3 \%$, and microenterprises by $23.11 \%$ in relation to 2010. Over the next year, negative dynamics persisted, but not to the same extent as in 2011. According to the results of 2013-2015, there was an improvement in the situation. So, in 2013 the growth in the number of small enterprises amounted to $7.81 \%$, and microenterprises $-8.37 \%$ compared to 2012 .

In 2014, there was a significant increase in the number of small and micro-enterprises by $12.5 \%$ and $13.6 \%$ respectively. In 2015 , the growth rate of the number of enterprises decreased, and in 2016, there was already a negative trend.

The end of 2018 showed that the number of small and microenterprises was growing but not more than $1.5 \%$ compared to the previous period.

Summing up, we note that during 20112018 the total number of small and micro businesses was falling within $17.5 \%$, which indicates a deterioration in the level of development of private entrepreneurship in Ukraine. The reason for this situation is the unsatisfactory state of the national economy and the great influence of political and legislative threats on the activities of enterprises. 


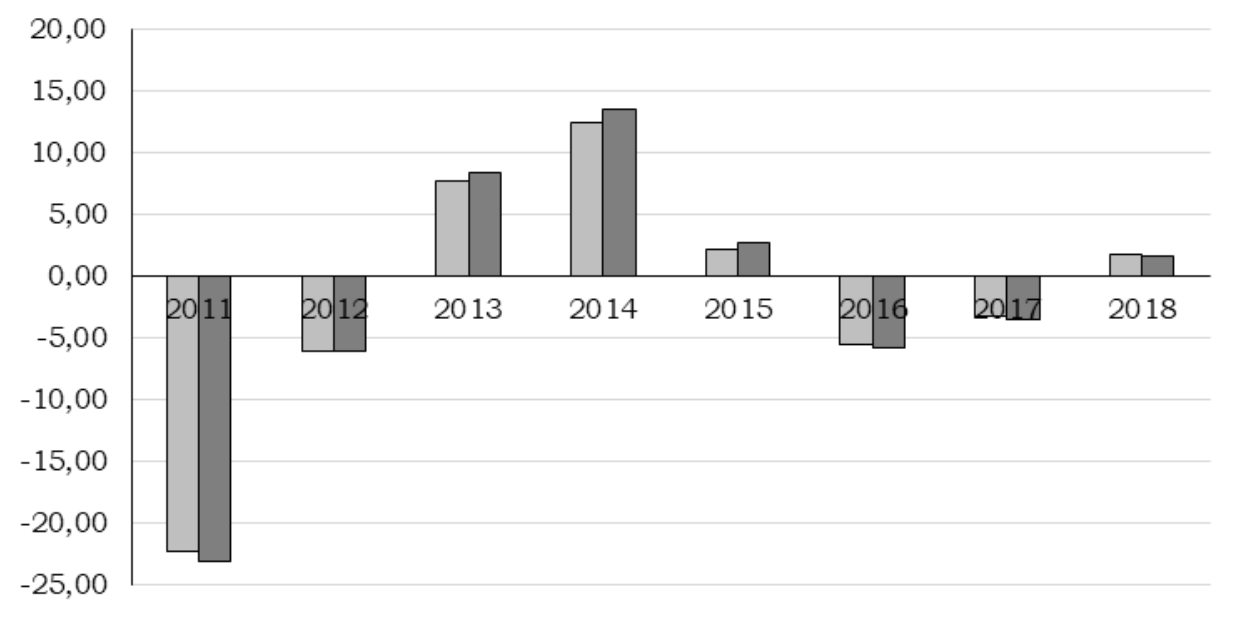

$\square$ The growth rate of the number of small enterprises, $\%$

$\square$ The growth rate of the number of microenterprises, \%

Fig. 1. The growth rate of the number of small and microenterprises in 2011-2018

Source: built by the author according to the data (State Statistics Service of Ukraine, 2020)

Based on the foregoing, the development of small and microenterprises in Ukraine requires ensuring their economic security and developing proposals for a strategy. This will prevent the negative consequences of the implementation of a number of threats.

To ensure the economic security of the enterprise, it is advisable to use the term 'threat', because it involves the formation of a state of protection from possible dangers, namely from the events that negatively affect the state of the business entity. To ensure economic security, it is necessary to determine the components that reflect the conditions for preventing the occurrence of negative consequences on the development of the enterprise.

The economic security structure should contain components that will neutralize the negative consequences of threats. Given the conditions for the development of small and microenterprises, an economic security structure has been formed (Fig. 2), which includes four components of economic security: innovative security, business security, safety of competitiveness and financial and legal security. We describe the features of each of the above components.

According to Fig. 2, ensuring innovative security involves a number of threats associated with the non-use of innovative tools in the processes of product sales and advertising. By the latter one, we mean Internet resources, namely Facebook, Instagram, TikTok and YouTube. It is also necessary to say about the feasibility of establishing product sales through the Viber, Telegram and WhatsApp applications. For example, the Viber application has an interesting "Community" function, which allows you to establish high-quality contact with an individual customer. Using the above resources will allow small and micro businesses to conduct advertising campaigns and sell products without reference to the geography of the store, which means developing a customer base.

Considering the safety of entrepreneurship, we note that in most cases small and microenterprises operate under the supervision of an individual entrepreneur. Therefore, for successful management, individual qualities of the person who owns the business are very important. Neutralization of unaware threats can be implemented by continuous improvement of the qualifications of an individual entrepreneur through training, seminars and courses.

Competition safety implies the ability of an enterprise to achieve its goal, provided that there are a large number of competitors. In the conditions of small and microenterprises, the primary element of competitiveness is the formation of a competitive advantage; it does not provide for dumping prices. Small and microenterprises are less protected from possible threats, so the constant loss of competitive advantage is an everyday occurrence. The existing competitive advantage should be as flexible as possible, which will allow us to continuously improve it and adjust it to the competitive market. In turn, the above will provide a stable sales market.

Financial and legal security involves protecting the company from threats to financial stability in connection with an insufficient level of self-financing, and, consequently, raising credit funds. In the conditions of small and micro-entrepreneurship, it is advisable to divide 
the given component of economic security into financial and legal parts because successful resolution of financial issues depends on the legal knowledge of the head of business.

The foregoing prompts reflection on a comprehensive development strategy for small and microenterprises. To do this, we propose to turn to partnership strategies. The latter involves the conclusion of partnership contracts with enterprises that work effectively in various sectors of the economy. Fig. 2, showing com- ponents of economic security, suggests the consideration of the following strategic partnership agreements: marketing, logistics, integration, legal and financial. The implementation of the proposed strategy will lead to the involvement of specialists in various fields of activity and the increase of the level of economic security. The latter is a reasonably possible synergistic effect from fruitful cooperation.

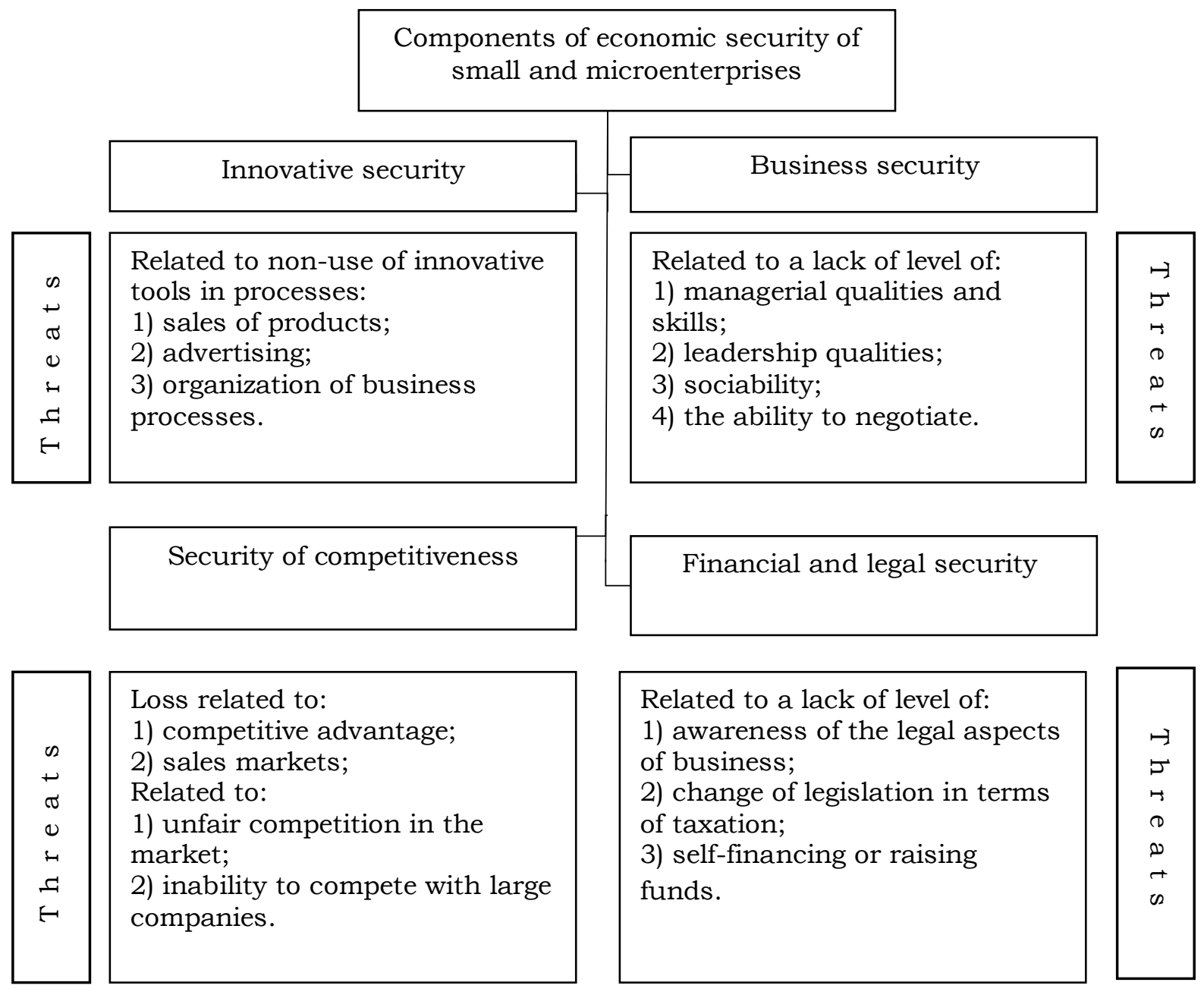

Fig. 2. Components of economic security of small and microenterprises

Conclusions. This study of the state of development of the small and micro business system in Ukraine encourages the development of an economic security system. Hopefully, the latter will prevent a reduction in the size of the given group of enterprises in the future. The following conclusions are drawn based on the results of the study:

1. In recent years, the number of small and microenterprises has been declining in Ukraine. The above occurs for reasons of state failure to stimulate the development of small and microenterprises.

2. The essence of economic security in the context of small and microenterprises has been studied. It was determined that in ensuring the latter it is necessary to take into account the following components: innovative security, competitive security, business security and financial and legal security.

3. Based on the proposed structure of economic security, relevant threats have been identified and ways to neutralize them have been proposed.

4. To prevent the negative consequences of the implementation of threats, it is proposed to use the strategy of partnership agreements. This will allow attracting enterprises of various orientations to cooperation and obtain a synergistic effect in the future. 


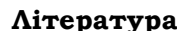

1. Заяц Ю. О. Особенности и угрозы обеспечения экономической безопасности Украины. Экономика $u$ менеджмент инновационных технологий. 2016. № 3. URL: http://ekonomika.snauka.ru/2016/03/11078 (дата звернення: 01.05.2020).

2. Назаров Н. К., Бараннік I. О. Економічна безпека експортно-імпортного потенціалу підприємства. Бізнес Інформ. 2019. № 5. С. 142-149. DOI: 10.32983/2222-4459-2019-5-142-149.

3. Ареф'єва О. В., Кузенко Т. Б. Економічні основи формування фінансової складової економічної безпеки. Актуальні проблеми економіки. 2009. № 1(91). С. 98-103.

4. Проблеми управління економічною безпекою суб’єктів господарювання : монографія / О. А. Кириченко та ін. К. : ІМБ Університету економіки та права "КРОК", 2010. 412 с.

5. Ioan-Franc V., Diamescu M. A. Some Opinions on the Relation between Security Economy and Economy

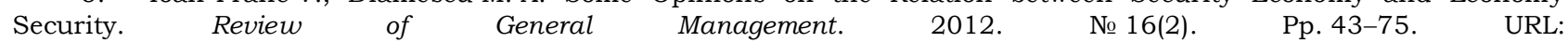
https://ideas.repec.org/a/fmb/journl/v16y2012i2p43-75.html (дата звернення: 01.05.2020).

6. Efimovich Melev S. Economic Security as a Scientific Category: Theoretical and Methodological Aspect of Research. Annales Universitatis Mariae Curie-Sklodowska Lublin - Polonia. 2014. Vol. XXXIX(2). Pp. 81-91.

7. Мігнус I. П., Ааптєв С. М. Необхідність розмежування поняття "загроза" та "ризик" при діагностиці економічної безпеки суб’єктів господарювання. Ефективна економіка. 2011. № 12. URL: http://www.economy.nayka.com.ua/?op=1\&z=821_(дата звернення: 01.05.2020).

8. Нусінова О. В. Класифікація складових безпеки підприємства на основі аналізу загроз. Бізнес Інформ. 2011. № 8. C. 96-99. URL: https://www.business-inform.net/annotated-catalogue/?year=2011\&abstract=2011_08_ 0\&stqa $=25 \&$ lang $=$ ru (дата звернення: 01.05.2020).

9. Тульчинська С. О., Ткаченко Т. П., Гращенко М. В. Загрози економічної безпеки малого підприємництва. Інвестииії: практика та досвід. 2017. № 23. С. 31-33.

10. Державний комітет статистики України : веб-сайт. URL: http://www.ukrstat.gov.ua/ (дата звернення: 26.04.2020).

\section{References}

1. Zajac, J. O. (2016). Features and threats to the economic security of Ukraine. Economics and innovations management, 3. Retrieved from http://ekonomika.snauka.ru/2016/03/11078 (in Russian)

2. Nazarov, N. K., \& Barannik, I. O. (2019). Economic Security of Export-Import Potential of an Enterprise. Business Inform, 5, 142-149. (in Ukrainian)

3. Aref ieva, O. V., \& Kuzenko, T. B. (2009). Ekonomichni osnovy formuvannia finansovoi skladovoi ekonomichnoi bezpeky. [Economic Foundations of the financial component of economic security]. Aktualni problemy ekonomiky, 1, 98103. (in Ukrainian)

4. Kirichenko, O. A., \& Sidak, V. S. (Eds.). (2010). Problems of managing economic security of business entities : monograph. Kiev: IMB University of Economics and Law "KROK». (in Ukrainian)

5. Ioan-Franc, V., \& Diamescu, M. A. (2012). Some Opinions on the Relation between Security Economy and Economy Security. Review of General Management, 16(2), 43-75. URL: https://ideas.repec.org/a/fmb/journl/v16y2012i2p43-75.html.

6. Efimovich Melev, S. (2014). Economic Security as a Scientific Category: Theoretical and Methodological Aspect of Research. Annales Universitatis Mariae Curie-Sklodowska Lublin - Polonia, XXXIX(2), 81-91.

7. Mihus, I. P., \& Laptiev, I. P. (2011). The need for the distinction between "threat" and "risk" in the diagnosis of economic security entities. Efektyuna ekonomika, 12. Retrieved from http://www.economy.nayka.com.ua/?op=1\&z=821. (in Ukrainian)

8. Nusinova, O. V. (2011). Classification of components of enterprise security based on threat analysis. Business Inform, 8, 96-99. Retrieved from https://www.business-inform.net/annotated-catalogue/?year=2011\&abstract= 2011_08_0\&stqa $=25 \&$ \&lang=ru. (in Ukrainian)

9. Tulchynska, S., Tkachenko, T., \& Hrashchenko, M. (2017). Threats of economic security of small enterprise. Investytsiyi: praktyka ta dosvid, 23, 31-33. (in Ukrainian)

10. State Statistics Service of Ukraine. (2020). Statistical Information. Retrieved from http://www.ukrstat.gov.ua/.

Стаття надійшла до редакції 05.05.2020 p. Стаття прийнята 15.05.2020 p. 